Kinga Stopczyńska ${ }^{1}$

Wydział Zarządzania

Katedra Marketingu

Uniwersytet Łódzki

\title{
WYKORZYSTANIE FACEBOOKA W KREOWANIU RELACJI Z KLIENTEM NA PRZYKŁADZIE MAREK OSOBISTYCH
}

\section{Abstract \\ THE USE OF FACEBOOK IN CREATING A RELATIONSHIP WITH THE CLIENT ON THE EXAMPLE OF PERSONAL BRANDS}

Creating a personal brand is when the current market conditions one of the most popular activities undertaken. Personal brand is gaining on its potential value also becoming emotional nature. The bond linking her with her repeatedly buyer goes beyond the standard approach of strategic communication campaigns. Based on the recipient's emotions, trying to be the most engaging, with time, become an important part of life recipient. Same social media are tools, usually unpaid, allowing in a permanent dialogue with existing fans of the brand and potential future - because it allows also to establish contacts with people. Building this special bond is possible through continuous contact with the customer, based on dialogue. Perfectly suited such a situation of social media. Thanks to the activities in social media, the brand becomes visible to humans. In addition, they allow you to create your own content. Such tools are blogs - or online journal, video and photo sites, social networking sites, forums, and even podcasts and Internet radio. One of the most frequented social networking is Facebook. It was he who offered the holidays due to the possibility of actions that may be in the context of use has become much preferred tool for creating personal brands through building relationships and customer relationships. The successes generated by the personal brand using Facebook to relational activities are no longer just incidental but with proper involvement of the same brand become almost the norm. It is an excellent source of motivation but also an innovative idea for a business activity that is thanks to the strong personalize these actions may allow to generate a completely new quality on the market.

Key words: personal brand, social media, relations, Facebook, image

\footnotetext{
${ }^{1}$ Adiunkt, Uniwersytet Łódzki, Wydział Zarządzania, Katedra Marketingu.
} 


\section{Wstęp}

Budowanie relacji z klientami należy obecnie do jednych $\mathrm{z}$ najistotniejszych działań, jakie podejmują marki. Tempo zmian we współczesnym świecie jest tak duże, że żadna organizacja nie może samodzielnie kontrolować - ani tym bardziej przywłaszczać sobie - wszystkich skutecznych praktyk operacyjnych i pomysłów ${ }^{2}$. Nie wystarczy wyłącznie doskonała jakość, aby zrobić wrażenie na kliencie. Potrzeba znacznie więcej, a najsilniejszy nacisk kładziony jest na emocje, które klient powinien bezpośrednio odczuwać w powiązaniu z daną marką. Działania te nie mogą być jednak prowadzone w oderwaniu od całej strategii komunikacyjnej, co więcej, powinny być jej częścią składową, tak by w wyniku efektu synergii przełożyły się na jej sukces. Ewolucja rynku i jego ciągłe zmiany to również progres w oczekiwaniach klienta, który stał się bardziej wymagający w obszarach komunikacji z nim i kreowania relacji na poziomie dającym mu niemal realny udział $\mathrm{w}$ tworzeniu marki. Dostęp do nieograniczonego rynku informacji i narzędzi, za pomocą których można je pozyskiwać w zupełnie naturalny sposób, stworzył społeczeństwo informacyjne, które stawia duże wymagania co do transferu informacji dotyczących marek. Informacja ma być przekazywana jak najszybciej - najlepiej w czasie rzeczywistym, ma mieć doskonałą wartość wizualną, ale - co najważniejsze - powinna nieść z sobą realną wartość dla samego klienta. Tym samym marka ma mieć charakter angażujący, wielokrotnie również motywujący i aspiracyjny. Ważne jest również to, za pomocą jakich kanałów przekaz ten będzie dystrybuowany i czy dają one szansę na współtworzenie ich przez samego odbiorcę komunikatu - tego bowiem on oczekuje.

Obserwując rynek, zauważymy, że doskonałym medium, które spełnia niemal wszystkie wyżej wymienione wymagania klienta, jest Facebook. Szybkość, jakość, zasięg i kreatywność to cechy, które są niejako immanentnymi cechami tego medium. To, w jakim stopniu zostaną wykorzystane, zależy wyłącznie od nadawcy danego komunikatu. Relacyjność działań podejmowanych na Facebooku została już dostrzeżona przez wiele marek i z dużymi sukcesami wykorzystywana jest na co dzień. Doświadczenia rynkowe marek komercyjnych okazały się doskonałym źródłem inspiracji dla marek osobistych, dla których platforma, jaką jest Facebook, zaczęła być niemal idealnym miejscem nie tylko do zaistnienia, ale przede wszystkim do zebrania oddanej publiczności odbiorców. Ponieważ obserwacje rynkowe skłaniają do przekonania graniczącego z pewnością, że właśnie Facebook będzie w przyszłości mekką marek osobistych, dlatego też tematyka ta stała się przedmiotem wywodu, który zostanie tutaj poprowadzony. Co więcej, obserwując media społecznościowe, łatwo można wyciągnąć wnioski, że jest to przestrzeń wręcz predestynowana do takich działań, co widać po efektach, jakie realizują poszczególne marki osobiste.

${ }^{2}$ Ch.E. Bogan, M.J. English, Benchmarking jako klucz do najlepszych praktyk, Helion, Gliwice 2006, s. 21. 
Celem wywodu będzie przeanalizowanie, w jaki sposób Facebook daje możliwość kreowania relacji z adresatami właśnie marek osobistych.

Wnioski zostaną oparte na analizie literatury $\mathrm{z}$ zakresu tematu, jak i na wynikach obserwacji współuczestniczącej autorki, czyli czynnym współuczestniczeniu w rozwoju wybranego na potrzeby wywodu fanpage’a, za pomocą którego marka nie tylko kreuje swój wizerunek, ale przede wszystkim dba o relacje $\mathrm{z}$ fanami. Ze względu na ograniczoną objętość wywodu studia literaturowe poparto jednym case study marki osobistej, biorąc jednak pod uwagę działania, jakie są podejmowane w ramach jej kreowania, można uznać ją jako wzorcową.

\section{Facebook jako medium kreowania relacji}

W demokratycznych społecznościach XXI wieku, ludzie odczuwają potrzebę komunikacji opartej na publikowaniu swoich myśli, przekonań i upublicznianiu ich szerokiej grupie odbiorców ${ }^{3}$. Udostępnianie treści innym członkom społeczności to dziś istotny element całości, jaką są media społecznościowe $e^{4}$.

Facebook jest obecnie najbardziej dochodowym z portali społecznościowych. Co więcej, to właśnie on generuje największą liczbę użytkowników, którzy spędzają na portalu znaczną część swojego czasu. Lider mediów społecznościowych, za jakiego można uznać Facebook, w dniu 30 lipca 2015 roku ogłosił imponujące wyniki za II kwartał. Liczba użytkowników wzrosła do niemal 1,5 mld, a przychody wzrosły o $39 \%$. Aż $76 \%$ przychodów firmy pochodzi z reklamy mobilnej, podczas gdy w II kwartale 2014 roku było to $62 \%$. Użytkownicy spędzają średnio 46 minut dziennie na aplikacjach mobilnych Facebooka, a z portalu co najmniej raz w miesiącu korzysta 1,49 mln użytkowników, z czego $968 \mathrm{mln}$ minimum raz dziennie. Na urządzeniach mobilnych raz w miesiącu zagląda na Facebooka 1,31 mld osób5. Podstawowym kryterium decydującym o tym, czy sany serwis jest atrakcyjny pod względem reklamowym, jest liczba oraz profil jego użytkowników ${ }^{6}$. Ten warunek wydaje się spełniony w przypadku Facebooka.

Co więcej, z wyżej przedstawionych faktów, a także z obserwacji tego medium można wnioskować, że Facebook wciąż powiększa liczbę użytkowników, a oni coraz częściej i chętniej go odwiedzają. Jak na razie nic nie wskazuje na wyraźną zmianę tego trendu. Według badania przeprowadzonego przez platformę Gi-

3 J. Walker Rettberg, Blogging: Digital Media and Society Series, Polity Press, Cambridge 2014, s. 90.

${ }^{4}$ L. „Li” Evans, Social Media Marketing. Odkryj potencjał Facebooka, Twittera i innych portali społecznościowych, Helion, Gliwice 2011, s. 22.

${ }^{5}$ Facebook notuje rekordowe wyniki, „Forbes”, 30.07.2015, http://www.forbes.pl/facebook-notuje-rekordowe-wyniki,artykuly,197681,1,1.html\# [dostęp: 30.07.2015].

${ }^{6}$ G. Mazurek, Promocja w Internecie. Narzędzia, zarządzanie, praktyka, Ośrodek Doradztwa i Doskonalenia Kadr, Gdańsk 2008, s. 78. 
gya w pierwszym kwartale 2015 roku Facebook zdobył niekwestionowane pierwsze miejsce w rankingu liczby logowań do różnych mediów społecznościowych. Zyskał on $64 \%$, co stawia go daleko przed drugim w zestawieniu Google+ i Twitterem, który po raz pierwszy wyprzedził Yahoo. Ostatni z wyróżnionych portali jest LinkedIn, mający minimalną popularność. Podobne są wyniki w poszczególnych kategoriach: sprzedaży, podróży, edukacji czy mediów. Także na wszystkich badanych kontynentach proporcje są bardzo zbliżone ${ }^{7}$.

Facebook to nie tylko miejsce, w którym użytkownicy spędzają swój wolny czas na zabawie, rozmowach ze znajomymi, ale również miejsce, w którym poszukują informacji, miejsce, które kreuje ich światopogląd, w końcu miejsce, które jest dla nich jednym z pierwszych, kiedy poszukują informacji o danej marce. Wykorzystując inspiracyjną stronę inbound marketing 8 , na którym niemal wyrosły całe social media, Facebook nie jest inwazyjny i nachalny, a wybierany w sposób intencyjny i świadomy przez samego użytkownika. Cechy te powodują, że marki bardzo intuicyjnie zaczynają już nie tylko testować jego możliwości, ale i wykorzystywać go do budowania swojej przewagi konkurencyjnej.

Facebook stał się niejako wizytówką samych marek i ich poczynań rynkowych. Poszczególne fanpage'e stały się pamiętnikami życia marki, na których czytanie dają przyzwolenie swoim fanom. Dzięki możliwości pełnej interaktywności, jaką daje Facebook, współuczestniczenie w życiu marki ma wymiar real-time marketing ${ }^{9}$ i pozwala na natychmiastową reakcję nie tylko samej marki, ale przede wszystkim jej fanów. Naturalnym tego skutkiem jest stworzenie pewnej więzi, często bardzo intymnej i prywatnej na polu marka-klient, co wpisuje się w obecnie obowiązujące trendy marketingu relacji.

\section{Budowanie relacji z publicznością}

Jak wcześniej wspomniano, obecnie najbardziej aktualnym trendem na rynku jest właśnie marketing relacji. Trudno sobie wyobrazić takie działania bez odpowiedniego zaangażowania samej marki i ludzi ją tworzących. Jak ważną rolę odgry-

${ }^{7}$ M. Marchwicki, Facebook rządzi i dzieli, „SocialPress”, 27.04.2015, http://socialpress.pl/2015/04/ facebook-rzadzi-i-dzieli/\# [dostęp: 10.06.2015].

${ }^{8}$ Działania zakładające nienachalną, opartą na komunikatach mających realną wartość dla klienta komunikację, która inspiruje go do poszukiwania informacji o marce, a nie zakłada nachalnego zarzucania go treściami o tej tematyce. W założeniu odbiorca komunikatu jest odkrywcą niuansów marki, a zadaniem nadawcy komunikatu jest wcześniejsze przygotowanie treści, które będą zachęcały do dalszych i jeszcze bardziej wnikliwych poszukiwań informacji z nią związanych.

9 Działania komunikacyjne oparte na dystrybuowaniu informacji w czasie rzeczywistym. Real-time marketing opiera się w swoim założeniu przede wszystkim na dynamicznym i, co ważne, spersonalizowanym kontencie dystrybuowanym wielokanałowo jego odbiorcom, przy założeniu natychmiastowej reakcji na niego. 
wa w budowaniu relacji personel firmy mówi definicja Kazimierza Rogozińskiego: „Marketing relacji oznacza mobilizację personelu mającą na celu uczynić z nabywcy nie tylko współtwórcę wartości - produktu, ale związać go na stałe z firmą"10. Warto zwrócić uwagę, że dzisiejsze sukcesy rynkowe opiera się właśnie na interakcji człowiek-człowiek, kluczowa jest więc implementacja założeń relacyjnych właśnie do filozofii firmy i świadomości jej pracowników.

Marketing relacji jest bardzo blisko związany z tzw. permission marketing. Jeszcze kilka lat temu (na rynku polskim niestety w wielu przypadkach nadal) powszechne było przekonanie, że tylko i wyłącznie intensywne kampanie komunikacyjne mają szansę być skuteczne. Klienci byli zasypywani reklamami telewizyjnymi, radiowymi, na każdym kroku towarzyszyły im billboardy promujące produkty, które najlepiej powinny zaspokajać ich potrzeby. Obserwując zachowania klientów na rynku polskim, rzeczywiście mogło się wydawać, że takie działania były skuteczne i klienci faktycznie byli zafascynowani reklamami, uznając je za coś bardzo wyjątkowego. Stanowiły one dla nich formę rozrywki, a nawet stawały się tematami do rozmów towarzyskich. Humorystycznie mawiano, że reklamy niepotrzebnie przerywane są nudnymi i nikogo nieinteresującymi filmami.

Tak wyglądała rzeczywistość początku lat dziewięćdziesiątych. Powoli jednak klienci odczuli przesyt przekazami promocyjnymi firm. Działania, których celem było nakłonienie klienta do zakupu produktu, odnosiły wręcz odwrotny skutek. Nie jest przesadą twierdzenie, że działania marketingowe towarzyszą prawie każdemu obszarowi życia klientów, często zamiast pomagać np. w podejmowaniu decyzji zakupowej, irytują i przeszkadzają. To właśnie kwintesencja interruption marketing ${ }^{11}$.

Mimo to nadal wielu marketerów wydaje się tego nie zauważać i nie radzi sobie z problemem coraz trudniejszego dotarcia do klienta, paradoksalnie stosując interruption marketing w jeszcze większej skali. Część zwiększa wydatki promocyjne, przy czym nie dokonuje dywersyfikacji wybranych mediów i regularnie umieszcza w nich wciąż takie same komunikaty. Inni próbują tworzyć komunikaty bardziej zabawne lub kontrowersyjne. Okazuje się, że istnieje alternatywa, która już $\mathrm{z}$ dużym powodzeniem wykorzystywana jest na rynkach zagranicznych, ale również coraz chętniej, i to z sukcesami, na rynku polskim. Koncepcja nazywa się permission marketing ${ }^{12}$, a jednym $\mathrm{z}$ głównych jej promotorów jest Seth Godin, jeden $\mathrm{z}$ wiceprezydentów Yahoo! Inc. Opiera się ona przede wszystkim na komunikowa-

${ }^{10}$ K. Rogoziński, Nowy marketing usług, Wydawnictwo Akademii Ekonomicznej w Poznaniu, Poznań 1998, s. 36.

${ }^{11}$ Działania te często nazywane są marketingiem rozpraszającym, skupiającym się przede wszystkim na próbach jak najczęstszego, często bardzo nachalnego kontaktu firmy/marki z klientem. Optymalizacja działań zakłada tutaj przede wszystkim ciągły kontakt klienta z komunikatem, wykorzystując w tym celu wszelkie możliwe kanały komunikacyjne.

${ }_{12}$ Działania opierające się na dystrybuowaniu komunikatów przy jednoczesnym wyrażeniu zgody na ich otrzymywanie przez odbiorcę. Odbiorca poszukuje informacji, które korespondują z jego potrzebami, deklaruje chęć ich otrzymywania i staje się ich beneficjentem. 
niu z klientem przy jego wyraźnym przyzwoleniu, tym samym w sposób mu przyjazny i dający realne szanse na zapamiętanie danego komunikatu. Istnieją bowiem szacunki, że na przykład mieszkaniec Stanów Zjednoczonych styka się codziennie $\mathrm{z}$ około trzema tysiącami komunikatów marketingowych ${ }^{13}$. Dla przykładu, przeciętny polski internauta spędzał $\mathrm{w}$ internecie $\mathrm{w} 2015$ roku 73 godziny miesięcznie. Życia bez internetu nie wyobrażała sobie prawie 1/3 osób w wieku 18-24 lat. Dziś wyzwaniem jest już nie tyle zapewnienie dostępu do sieci, ile edukacja na temat odpowiedzialnego używania cyfrowych narzędzi.

Zacytujmy wypowiedź Ewy Krupy - prezes Fundacji Orange: „Zmiany, które zaszły w obszarze korzystania $\mathrm{z}$ technologii w ciągu ostatnich lat, są wręcz rewolucyjne. Jeszcze 10 lat temu z internetu korzystało zaledwie 30\% Polaków, dziś ponad $2 / 3$. Czas statystycznie spędzany przez internautów w sieci wynosił 20 godzin miesięcznie, a obecnie to już ponad 70 godzin" ${ }^{14}$. Według badania sondażowego zrealizowanego przez IBRIS dla Fundacji Orange w ostatnich 10 latach internet miał największy wpływ na zdobywanie wiedzy i informacji (53\% badanych), załatwianie spraw finansowych (44\%) oraz komunikację ze znajomymi i rodziną (42\%). Zmiany technologiczne w szczególnym stopniu wpłynęły na młode pokolenie Polaków. Dziś odsetek internautów w grupie wiekowej 14-18 lat wynosi niemal $100 \%{ }^{15}$. Nie ma szansy, by każdy z nich zapamiętał wszystkie marki, z pewnością jednak prawdopodobieństwo rośnie w przypadku tych firm, którymi wykazuje on rzeczywiste zainteresowanie.

Biorąc pod uwagę rosnącą siłę internetu, jak również zwiększającą się ilość komunikatów marketingowych, dystrybuowanych właśnie za pomocą działań on-line, można przyjąć, że rola permission marketing rośnie każdego dnia. Internet różni się od mediów tradycyjnych mniejszą inwazyjnością w sposobie prezentacji przekazów reklamowych. Można powiedzieć, że internet jest medium interaktywnym i syntezowym, co sprawia, że na każdej z płaszczyzn kontaktu użytkownika z medium jego wpływ jest inny ${ }^{16}$.

Naturalne wydawać by się mogło, że dane przytoczone wyżej powinny mieć inspirujący wpływ na podmioty już działające w internecie i te, które dopiero planują w nim swoją obecność. Co więcej, powinny je inspirować właśnie w kierunku działań z zakresu permission marketing, czyli komunikatów, które mają nie przeszkadzać odbiorcy, a opierać się na wyrażonym przez niego przyzwoleniu na ich otrzymywanie. Jednocześnie warto podkreślić, że działania z tego zakresu często są mylone

${ }_{13}$ M. Wojciechowski, Psychologia sprzedaży. Permission marketing, http://clienting.blox. pl/2008/05/Permission-marketing.html [dostęp: 1.10.2015].

${ }^{14}$ Statystyczny Polak spędza $w$ sieci ponad 70 godzin miesięcznie. Nie każdy potrafi $w$ petni wykorzystać cyfrowe możliwości, Biznes NewSeria, 5.11.2015, http://www.biznes.newseria.pl/news/statystyczny_polak_spedza,p1201126379 [dostęp: 1.12.2016].

${ }_{15}$ Ile czasu w sieci spędza statystyczny Polak?, WP finanse, 6.11.2015, http://finanse.wp.pl/ kat,1033701,title,Ile-czasu-w-sieci-spedza-statystyczny-Polak,wid,17956845, wiadomosc. html?ticaid=1184f0 [dostęp: 1.11.2015].

16 A. Leśniewska, Reklama internetowa, Helion, Gliwice 2006, s. 72. 
z marketingiem bezpośrednim, przy czym główna różnica między nimi polega na tym, iż w przypadku tego drugiego to firma daje sobie zgodę na komunikację, wpisując ją w swoje działania, a nie sam odbiorca. Zobrazować to możemy wypowiedzią Setha Godina: „Jeśli 5\% respondentów bezpośredniej komunikacji odpowiedziało pozytywnie na nasz komunikat - oznacza to, iż 95\% go zignorowało" ${ }^{17}$.

Tego typu statystyki odbioru komunikatu dla firmy są bardzo jasną wskazówką, że niestety 95\% osób może nie akceptować jej przekazów, w sytuacjach skrajnych potencjalny odbiorca może trwale je blokować. Sytuacja taka może nastąpić również $\mathrm{w}$ przypadku nieumiejętnego korzystania $\mathrm{z}$ permission marketing. Mimo że sam odbiorca wyraził zgodę na otrzymywanie informacji, zbyt duża ich ilość lub nieumiejętne konstruowanie ich treści będzie skutkowało jego zniechęceniem, a w dłuższym okresie irytacją.

$\mathrm{Na}$ czym więc polega innowacyjność formy, jaką jest permission marketing? Przede wszystkim działania opierają się na zgodzie na otrzymywanie komunikatu i często na potrzebie komunikacji wyrażonej przez samego klienta. Działania te, właśnie ze względu na bezpośredni ich charakter, powinny być oparte na dialogu i znajomości preferencji i oczekiwań odbiorcy. Kluczowa jest zawsze pierwsza faza, kiedy to działania skupione powinny być na tym, by klient nie tylko wyraził zgodę na otrzymywanie komunikatu, ale sam o niego zabiegał. Ogromne znaczenie z punktu widzenia innowacyjnych rozwiązań komunikacyjnych będzie miał tutaj czynnik inspirujący - motywowanie odbiorcy komunikatu do poszukiwania treści. Wydaje się, że koncepcja permission marketingu jest zgodna z szerszym nurtem marketingu relacji, z którego przecież wywodzą się zasady systemów CRM. Obie te koncepcje opierają się na założeniu, że coraz kosztowniejsze i trudniejsze jest pozyskiwanie nowych klientów. Znacznie taniej jest lepiej obsługiwać klientów, z którymi mamy już jakiś kontakt - kupno produktu można uznać za rodzaj pozwolenia na dalszą komunikację i wykorzystać ten moment do rozpoczęcia budowania dalszych relacji z nimi. Z pewnością, podobnie jak w przypadku każdego działania komunikacyjnego znajdziemy głosy opowiadające się za tym, że permission marketing nie wnosi niczego nowego i dla wielu jest kopią działań wykorzystywanych w ramach marketingu relacji. Oba narzędzia mają bowiem jedną cechę wspólną, i to właśnie relacja, jaką buduje się na platformie porozumienia nadawca komunikatu - jego odbiorca.

Mamy jednak i sceptyków, którzy negują zasadność podejmowania działań w ramach marketingu relacji. Są to przede wszystkim przedstawiciele orientacji wszechobecnej globalizacji i tym samym działań mających na celu ujednolicenie rynków, potrzeb i segmentów rynku niezależnie od wszystkich czynników otoczenia marketingowego, w jakich dana organizacja funkcjonuje. Opierając się na zasadach takiego podejścia do rynku, możemy oczywiście uznać, że klienci na całym świecie są do siebie podobni, a w następstwie tego można również spłycić ich ocze-

${ }_{17}$ Za: M. Wojciechowski, Psychologia sprzedaży... 
kiwania w stosunku do indywidualizacji komunikacji z nimi. Problem jednak polega na tym, że podobne potrzeby mogą być zaspokajane przez wiele różnych produktów, które są dla siebie substytutami. Zadaniem, jakie niesie z sobą marka, jest przede wszystkim zbudowanie pewności u klienta, że to $\mathrm{z}$ całą pewnością ona potrafi w pełni zaspokoić jego potrzeby w sposób najbardziej go satysfakcjonujący. Co więcej, związek z nią nie będzie krótkotrwały i jednorazowy, ale ma się przerodzić w dłuższą relację, z której obie strony będą czerpały korzyści. Można to zrobić, opierając się właśnie na komunikacji, która nie tylko niesie z sobą odpowiedni komunikat, ale przede wszystkim daje poczucie odbiorcy, że został on skonstruowany bezsprzecznie z myślą o nim. Dodatkowo za komunikatem powinna iść dalsza komunikacja oparta już na niemal bezpośrednim dialogu, dzięki któremu budować można przede wszystkim poczucie więzi z marką przekładające się w dłuższym okresie na lojalność w stosunku do niej i jej ambasadorowania.

Jednym z działań, jakie możemy podejmować $\mathrm{w}$ ramach marketingu relacji, które doskonale wpisuje się w wyżej wspomniane założenia, jest oczywiście wykorzystanie social medió $w^{18}$ ze szczególnym uwzględnieniem Facebooka, który sam $\mathrm{w}$ sobie opiera się na idei permission marketing. Okazuje się bowiem, że to narzędzie świetnie się sprawdza w kreacji trwałych relacji z klientami, na których to inicjację oni sami wyrażają zgodę. Kluczem będzie dopasowanie przekazu do oczekiwań odbiorcy. Maksymalnie precyzyjne dopasowanie treści zawartej na stronie docelowej do treści wezwania do działania ma ogromne znaczenie ${ }^{19}$.

\section{Marka osobista i jej specyfika}

Pojęcie marki jest pojęciem bliskim każdemu z nas, niemal każdy bowiem ma marki, które kojarzą mu się pozytywnie, wywołują uśmiech i zadowolenie. Jednocześnie prawie każdy zna marki, których wolałby unikać w przyszłości. Te odczucia związane z poszczególnymi markami są niejako podstawą, na której budowane są właśnie relacje. Praktyka rynkowa pokazuje, że najważniejsze w całym procesie relacyjnym jest wywoływanie jakichkolwiek emocji przez markę - bo przecież ich brak stanowi o jej śmierci rynkowej. Ponieważ pojęcie marki osobistej powstało z pojęcia samej marki, dlatego ważne jest, by osadzić je w biznesie w sposób, który istotnie może się przekładać w długim czasie na realne zyski takiej marki.

Sama marka w ujęciu najbardziej popularnym jest tym, co się czuje instynktownie w związku z produktem czy firmą ${ }^{20}$. Bardzo często marką jest sama nazwa fir-

${ }^{18}$ Media społecznościowe - najczęściej mają formę platform komunikacyjnych opartych na zasadach tworzenia społeczności połączonych wspólnymi zainteresowaniami, zezwalające na publikację treści przygotowywanych przez ich uczestników, dzielenia się nimi z innymi, udostępniania treści publikowanych przez innych uczestników, wykorzystujące założenia marketingu wirusowego.

19 B. Halligan, D. Shah, Inbound marketing, Helion, Gliwice 2010, s. 209.

${ }^{20}$ K. Rogoziński, Nowy marketing usług, s. 2. 
my, a w przypadku marki osobistej najczęściej wykorzystywane jest imię i nazwisko lub pseudonim, którym dana osoba się posługuje. Dzisiejszy rynek niejako wymaga, aby marka wyróżniała się na tle marek konkurencyjnych i sama dla siebie budowała jakość i wartość. Tylko wtedy mogą one być dystrybuowane na jej odbiorców. Sam dobry odbiór marki w dużym stopniu wpływa na jej sukcesy rynkowe i przekłada się na jej popularność, a tym samym zyskowność.

Marki mają trzy podstawowe znaczenia:

- orientacja - która pomaga wybrać spośród wielu propozycji daną markę;

- angażowanie - symbol, skojarzenie i indywidualny język;

- ufność - wywołanie pewności/zaufania dla danej marki u jej odbiorców.

Sam wizerunek marki - tak niezwykle istotny dla jej rynkowego istnienia - jest niemal lustrzanym odbiciem osobowości marki oraz samopoczucia jej użytkownika. Jest tym, co ludzie myślą o marce, czują w odniesieniu do marki, oraz tym, czego od niej oczekują ${ }^{21}$.

Na wstępie należy określić, czym jest marka osobista i jak działa ona na rynku. „Budowanie marki osobistej zawsze warto rozpocząć od ustalenia tego, jak chcemy być postrzegani”22. Oznacza to, że zaczynając kreować markę osobistą, powinno się skupić się na tym jak chcemy być odbierani, jakimi cechami chcemy się wyróżnić. W przypadku marki osobistej niezwykle ważny jest argument, że „markę osobistą ma każdy"23 niezależnie od tego, czy buduje się ją przez lata, czy też nie. Jest to immanentna cecha każdego $\mathrm{z}$ nas, jednak nie jest wykorzystywana przez każdego w celach komercyjnych. Mówi się, iż „marką jest to, co ludzie o Tobie mówią, gdy wyjdziesz z pokoju" ${ }^{24}$. Personal branding - tego określenia bardzo często używamy w stosunku do marki osobistej - jest to zarządzanie wizerunkiem osoby działającej w sferze publicznej: biznesie, nauce, polityce, mediach, sztuce, medycynie, prawie, sporcie - słowem wszędzie tam, gdzie odnoszone sukcesy, właściwie opowiedziane, budują pozycję osoby i zwiększają jej wartość 25 .

W przypadku Facebooka marki takie są tworzone przez każdego posiadacza profilu na tym portalu. Pozycja marki osobistej przekłada się na zainteresowanie nią, zaufanie do niej, jej dalsze polecanie, ale przede wszystkim zakupy odtwórcze danej marki. Marka osobista wyróżnia daną osobę, stanowiąc o jej unikatowości. Wskazuje na wartości, jakie marka ta reprezentuje, jaki kontent niesie z sobą

${ }^{21}$ M. Brzozowska-Woś, Social media and brand image, Uniwersytet Ekonomiczny w Krakowie, Kraków 2013, s. 43.

${ }_{22}$ P. Bucki, Personal branding, „Nowe Kompetencje”, 1.04.2014, http://blog.nowekompetencje. pl/artykuly/personal-branding [dostęp: 3.01.2015].

${ }_{23}$ A. Szubert, Każdy z nas ma markę osobistą. Jak uczynić ja silną?, „naTemat”, 5.09.2014, http:// annaszubert.natemat.pl/115899,kazdy-z-nas-ma-marke-osobista-jak-uczynic-ja-silna [dostęp: 3.01.2015].

${ }^{24}$ K. Budek, Marka osobista - klucz do kariery, 2011, http://manager.nf.pl/marka-osobista-kluczdo-kariery,,47819,24 [dostęp: 3.01.2015].

25 J. Wołyński, Marka osobista, 2011, http://jakubwolynski.pl/marka-osobista/ [dostęp: 21.05.2015]. 
i w jaki sposób może wpływać na życie i codzienność jej odbiorców. Silną markę osobistą kształtuje się bardzo często za pomocą realizacji obietnic, a nie tylko ich składania - jeśli adresaci marki ufają jej i dostają to, czego potrzebują, wówczas pozostają lojalni w stosunku do marki. Bardzo ważne jest, by budowanie marki osobistej opierało się na silnej podstawie stałych wartości reprezentowanych przez markę, ale jednocześnie by było urozmaicane „efektem wow”, czyli by posiadało w sobie znaczący element zaskoczenia, który powoduje, że odbiorca czuje prawdziwe zaangażowanie marki i tym samym docenienie go. Będąc właścicielem marki osobistej, należy współpracować z innymi, mieć z nimi kontakt i prowadzić z innymi dyskusje, aby ciągle poprawiać posiadaną ofertę i budować z innymi relacje. To one są podstawą budowania marki osobistej, ponieważ to dzięki nim informacja o samej marce jest przekazywana dalej.

Jednym z najistotniejszych elementów sukcesu marki wynikającego z relacji, jakie udało się jej zbudować z jej odbiorcami, jest przede wszystkim jej autentyczność. Szczególnie ważne jest to właśnie podczas komunikacji za pomocą Facebooka. Głównymi celami, dla których marki osobiste będą chciały wykorzystać media społecznościowe, będą bowiem:

- budowanie świadomości i tożsamości;

- wzmacnianie obecnej pozycji;

- tworzenie określonego wizerunku;

- budowanie zaangażowanej społeczności wokół marki;

- zwiększenie sprzedaży;

- generowanie ruchu na stronie firmowej.

Bez wizerunku, w który na stałe wpisana jest właśnie autentyczność, wydaje się to prawie niemożliwe, a na pewno bardzo trudne, ponieważ każdy z tych celów w długim okresie ma charakter relacyjny i na taki powinien się przekładać.

Działanie mające na celu komunikowanie z publicznością powinno być w pełni świadome, pozwala to bowiem wyróżnić się w branży, a co za tym idzie - fani będą chętniej chcieli współpracować z daną marką. Trzeba pamiętać, że silna, wyróżniająca się marka staje się obecnie źródłem dużej przewagi na rynku.

Z aktualnych statystyk za 2014 rok wynika, że na Facebooku w Polsce jest zarejestrowanych 12,4 mln użytkowników ${ }^{26}$. Wynik ten jest o 3\% wyższy w porównaniu $\mathrm{z}$ rokiem 2013. Zarówno więc w ujęciu globalnym, którego statystki przytaczane były wcześniej, jak i w odniesieniu do rynku polskiego lata świetności Facebooka trwają dalej i nic nie wskazuje na szybkie zdetronizowanie lidera social mediów. Warto podkreślić, że głównymi użytkownikami w Polsce są osoby w przedziałach wiekowych 19-25 lat ( 3,5 mln osób) oraz 26-33 lat ( 2,92 mln), czyli osoby pełnoletnie, świadomie podejmujące decyzje, a co za tym idzie, dobra grupa potencjalnych klientów. Bardzo ważnym trendem, którego absolutnie nie można pominąć,

26 A. Prejs, Facebook w Polsce - podsumowanie 2014 r. - infografika, „Sotrender”, 2.02.2015, http://blog.sotrender.com/pl/2015/02/facebook-polska-2014/ [dostęp: 3.06.2015]. 
jest wzrost aktywności osób starszych na Facebooku. Blisko 900 tys. osób w wieku 50+ posiada dziś własne konto społecznościowe. Liczba ta to wynik 14-procentowego wzrostu liczby założonych kont w 2014 roku.

W Polsce największym fanpage'em w roku 2015, z wynikiem ponad 2,4 mln, był należący do sieci Orange fanpage „Serce i rozum”. To właśnie sieci telekomunikacyjne zrzeszają największą liczbę fanów w naszym kraju. Oprócz sieci komunikacyjnych najlepiej prosperującą na Facebooku firmą jest Radio Eska oraz Tymbark - producent soków. Liderem wśród osób (muzyków, sportowców czy celebrytów) jest Kamil Bednarek zajmujący 12. miejsce w ogólnej klasyfikacji (łącznie z firmami) z wynikiem ponad 1,5 mln fanów.

Wyraźnie widać także wzrost znaczenia mediów na Facebooku. Co prawda na koniec 2014 roku profile markowe były większe niż strony prowadzone przez media średnio o 44\%, podczas gdy na początku roku różnica ta wynosiła $34 \%$, ale przeciętny profil z kategorii „Media” w ubiegłym roku powiększył liczbę swoich fanów średnio o $32 \%$, a profil markowy o $27 \%{ }^{27}$.

Coraz liczniejsze badania dowodzą, że Polacy zaczynają akceptować obecność marek w mediach społecznościowych. Wyniki badania „KNOW: Konsument w mediach społecznościowych" ${ }^{28}$, przeprowadzonego na zlecenie firmy Euro RSCG, wskazują, iż niemal jedna czwarta respondentów zadeklarowała, że dodaje profile marek czy firm do grona swoich znajomych, a następnie wchodzi z nimi $\mathrm{w}$ interakcję, regularnie komentując posty lub materiały zamieszczane na profilu marki. Większość osób decyduje się na interakcję z markami w serwisach społecznościowych ze względu na sympatię, jaką darzą dany produkt - robi tak aż 72\% ankietowanych ${ }^{29}$.

Potencjał ten wykorzystują na co dzień marki osobiste. O tym, że są to działania traktowane od strony biznesowej bardzo poważnie, stanowić może chociażby ujęcie ich w badaniach trendów związanych z aktywnościami na Facebooku prowadzonych co miesiąc przez Sotrender. Analiza wyników za miesiąc czerwiec 2015 jasno wskazuje, że gdy chodzi o marki osobiste:

- Największymi fanpage’ami w branży były: SA Wardęga, Ewa Chodakowska i Kamil Bednarek.

- Największy procentowy przyrost liczby fanów zaobserwowaliśmy na fanpageach: Martyny Wojciechowskiej, Magdy Gessler i Ewy Chodakowskiej.

27 Ibidem.

${ }^{28}$ Badanie „KNOW: Konsument w mediach społecznościowych” zostało przeprowadzone przez IMAS International Sp. z o.o. we Wrocławiu na zlecenie Euro RSCG Sensors. Miało formę ankiety internetowej i objęto nią osoby w wieku 18-64 lat, zarejestrowane w internetowym panelu badawczym IMAS OnLine. Respondenci $(n=538)$ to osoby, które korzystają z co najmniej dwóch serwisów społecznościowych raz w tygodniu.

29 B. Jaskowska, Raport: zaczynamy akceptować marki w serwisach społecznościowych, „InternetStandard" 24.03.2010, http://www.internetstandard.pl/news/357280/Raport.zaczynamy.akceptowac. marki.w.serwisach.spolecznosciowych.html [dostęp: 11.03.2014]. 
- W największym stopniu bazę fanów powiększyły fanpage’e: Martyny Wojciechowskiej, Ewy Chodakowskiej i CLEO.

- Najwięcej użytkowników Facebooka zaangażowały strony: Martyny Wojciechowskiej, Ewy Chodakowskiej i Anny Lewandowskiej.

- Największy odsetek zaangażowanych fanów obserwowaliśmy na stronach: Zbigniewa Stonogi, Roberta Biedronia oraz Jarosława „pasha” Jarząbkowskiego.

- Pod względem Interactivity Index najwyżej uplasowały się strony: Zbigniewa Stonogi (dawna), Ewy Chodakowskiej oraz Zbigniewa Stonogi.

- Wysokie Relative Interactivity każe zwrócić uwagę na strony: Zbigniewa Stonogi, Zbigniewa Stonogi (dawna) oraz Andrzeja Mleczki ${ }^{30}$.

Nazwiska znajdujące się najwyżej nie powinny nikogo dziwić, ponieważ to marki, które są budowane bardzo stabilnie, $\mathrm{z}$ wykorzystaniem przemyślanych strategii opartych właśnie na kreowaniu relacji ze swoimi fanami. W przypadku każdej $\mathrm{z}$ trzech marek zajmujących podium jej sukcesy przekładają się na dochodowość wyrażoną w pieniądzu $\mathrm{i}$ - co bardzo interesujące - każda $\mathrm{z}$ tych marek dokonuje transferu swojego zaangażowania ze świata wirtualnego na rynek klasyczny. Relacje budowane z fanami mają wymiar jak najbardziej realny - podobnie jak i kontakty między nimi. Sama wirtualność może bowiem wywoływać chwilowe zainteresowanie mające charakter mody, a nie silnego trendu rynkowego. W przypadku bardzo mocnej więzi z markami ich adresat chciałby mieć możliwość „dotknięcia” ich, a nie tylko czytania o nich. Wyraźnym, obserwowanym trendem jest obecnie budowanie silnej więzi emocjonalnej właśnie za pomocą Facebooka, ale po pewnym czasie uzupełnianie jej o kontakty face to face.

Relacyjność Facebooka oparta przede wszystkim na dużym zaangażowaniu fanów, motywowaniu i inspirowaniu ich do regularnego odwiedzania fanpagéa marki osobistej przekłada się na lojalność fanów, którzy często w krótkim okresie stają się ambasadorami marki. Udostępnianie przez nich treści publikowanych przez daną markę powoduje, że kolejne osoby dołączające do grona fanów mają już bardzo pozytywne nastawienie, ponieważ zostało ono zbudowane na rekomendacji ich znajomych. Ta forma buzz marketingu okazuje się niezwykle skuteczna, co więcej, daje dodatkowy bonus, jakim jest generowanie ludzi wokół marki, czyli tworzenie pewnej silnej społeczności ludzi, którzy nie tylko są jej fanami, ale często jej wyznawcami, ponieważ markę traktują niemal jak religię.

${ }^{30}$ Fanpage Trends 06.2015, „Sotrender”, http://www.sotrender.pl/trends/facebook/reports/201506/ludzie\#trends [dostęp: 30.07.2015]. 


\section{Ewa Chodakowska - czyli jak budować relacje z fanami}

Ewa Chodakowska to obecnie niekwestionowana liderka, jeśli chodzi o budowanie marki osobistej. Fenomen jej marki polega przede wszystkim na niezwykłym zaangażowaniu fanów w tworzenie jej fanpage’a przy jednoczesnym ciągłym motywowaniu ich do działania. Analizując rynek marek osobistych na Facebooku, można się pokusić o wskazanie kilku rodzajów zaangażowania/komunikacji w mediach społecznościowych, które mogą one wykorzystać. W przypadku Ewy Chodakowskiej są to:

- Komunikacja informacyjno-wizerunkowa - forma ciągłej relacji, czyli utrzymywanie na bieżąco kontaktu ze swoimi fanami, informowanie ich o wydarzeniach nie tylko $\mathrm{z}$ życia zawodowego, ale przede wszystkim $\mathrm{z}$ życia prywatnego. Informacje te dokładnie selekcjonowane powodują, że relacja między Ewą Chodakowską a jej fanami ma charakter niemal intymny. Angażowanie się w życie swoich fanów poprzez spersonalizowane wpisy na fanpage'u, używanie formy "ty” zamiast „wy” daje wymiar emocjonalny bliski relacjom przyjacielskim, który niemal natychmiast burzy dystans, jaki mógłby powstawać przy relacjach gwiazda-fan. To, co z pewnością wyróżnia jej działania, to szczerość przekazów, jakie przygotowuje dla swoich fanów, ale przede wszystkim komunikacja na poziomie przyjaciel-przyjaciel. Analizując wpisy fanów, można odnieść nieodparte wrażenie, że Ewa Chodakowska stała się ważną częścią życia tych ludzi, którzy traktują ją często niczym najbliższą i najbardziej zaufaną osobę.

- Komunikacja wizerunkowa - materiały kontentowe budowane $\mathrm{z}$ wykorzystaniem bogatego świata marki osobistej, np. szczegółowe relacje z imprez, w które gwiazda angażuje się w celach charytatywnych, udostępnianie postów mających na celu niesienie pomocy w trudnych sprawach. Ładunek emocjonalny, jaki niosą z sobą wpisy gwiazdy, powoduje, że fani bardzo szybko i chętnie angażują się w tego typu działania. Co ciekawe, w takich sytuacjach działają w sposób zorganizowany, ponieważ tworzą silną społeczność. Motywacją dla nich jest pochwała Ewy Chodakowskiej - jej podziękowanie i specjalnie dla nich przygotowany post. Mimo że jego odbiorców jest ponad $2 \mathrm{mln}$, charakter jego konstrukcji pozwala mieć przekonanie, iż był on przygotowany bardzo indywidualnie i dostosowany precyzyjnie do bieżących potrzeb odbiorcy.

- Komunikacja konkursowa - aktywność ta jest szczególnie lubiana przez fanów każdej marki, nie tylko marki osobistej. Dlatego właśnie również Ewa Chodakowska chętnie sięga po takie rozwiązania. W jej przypadku konkursy zawsze są związane z konkretnymi działaniami, jakie musi wykonać dana osoba, aby osiągnąć cel posiadania zgrabnej, zdrowej sylwetki. Wysiłek ten wymaga realnego zaangażowania, a mimo to podejmowany jest bardzo chętnie przez fanów. Na podkreślenie zasługuje tutaj fakt, iż Ewa Choda- 
kowska jako ambasadorka wielu marek, m.in. marki Adidas, chętnie wykorzystuje przestrzeń swojego profilu do komunikowania jej właśnie w konkursach dla swoich fanów.

- Komunikacja aktywizacyjna - Ewa Chodakowska nie tylko określa nowe cele przed swoimi fanami, ale również motywuje ich do działania, wyznaczając sobie coraz nowsze cele. Pokazując, jak sama pokonuje kolejne przeszkody, motywuje i inspiruje do podejmowania wysiłku. Działania realizowane przez nią mają nie tylko charakter motywacyjny, ale i silnie wspierający. Efektem jest transfer pewnego wizerunku, jaki już wypracowała dla fanów fanpage’a, którzy bardzo chętnie wcielają jej filozofię w życie profilu, motywując siebie nawzajem. To przykład prawdziwej społeczności osób połączonych z sobą nie tylko celem, jaki chcą osiągnąć, ale przede wszystkim stylem życia, którego punktem odniesienia jest sama Ewa Chodakowska.

Analizując działania tej konkretnej marki osobistej, niewątpliwy sukces można mierzyć liczbą fanów, która przekracza już $2 \mathrm{mln}$, ale przede wszystkim wskaźnikiem responsywności, jaki mierzony może być liczbą komentarzy i udostępnień, a także czasem reakcji na opublikowany post. Dodatkowo należy zwrócić uwagę na unikatową wartość, jaką jest absolutna lojalność w stosunku do marki Ewa Chodakowska. To już nie tylko sympatia do niej, ale cała dwumilionowa rzesza fanów, którzy nie tyko wspierają, ale i bronią jej w sytuacjach, kiedy pojawia się negatywny komentarz czy powątpiewanie. Nie bez powodu sami fani często nazywani się „wyznawcami Chodakowskiej”. Ewa stała się dla nich guru zdrowego stylu życia, mentorką i przewodniczką w świecie bycia fit, ale i w życiu codziennym.

Sukces tej marki ma jednak również inne, bardziej komercyjne oblicze - to setki tysięcy sprzedanych płyt DVD, to bardzo duża oglądalność programu telewizyjnego z Ewą Chodakowską, to w końcu wysoka sprzedaż magazynu „Be Active”, którego Ewa Chodakowska jest twarzą i zarazem redaktor naczelną.

Jej pierwsza książka - Zmień swoje życie z Ewą Chodakowska - podbiła serca czytelników, stając się tym samym liderem na liście bestsellerów Empiku. W ciągu zaledwie pół roku od jej premiery sprzedało się ponad 100 tys. egzemplarzy. Do tego dochodzą zyski ze sprzedaży płyty DVD (ponad 50 tys. sztuk) czy z udziału w kampaniach reklamowych Adidasa i współpraca z siecią Play. To wszystko mogło jej przynieść w sumie znacznie ponad 100 tys. złotych. Sam wizerunek Ewy Chodakowskiej jest wart już 300-400 tys. złotych ${ }^{31}$.

Biorąc pod uwagę powyższe informacje, trudno nie zgodzić się z faktem, że perfekcyjne wykorzystanie potencjału komunikacyjno-relacyjnego, jakim dysponuje Facebook, a przede wszystkim starannie dopracowana w każdym szczególe strategia samej komunikacji, stały się kluczem do sukcesu marki Ewa Chodakowska. Zaangażowanie w kreowanie silnej relacji z fanami znalazło wyraz w realnym

31 W Newsweeku: Ewa Chodakowska - trenerka - killerka - milionerka?, „Newsweek”, 10.11.2013, http://biznes.newsweek.pl/trenerka-killerka-milionerka-ile-zarabia-ewa-chodakowska-,artykuly,274327,1.html [dostęp: 21.05.2015]. 
biznesie i uplasowało ją na niekwestionowanym pierwszym miejscu, gdy chodzi o trenerki wszystkich Polek.

\section{Podsumowanie}

Kreowanie marki osobistej to w obecnych warunkach rynkowych jedno z najchętniej podejmowanych działań. Marka osobista zyskuje na swoim potencjale, stając się wartością również o charakterze emocjonalnym. Więź łącząca ją z jej nabywcą wielokrotnie wykracza poza standardowe ujęcie strategiczne w kampaniach komunikacyjnych. Wykorzystując emocje odbiorcy, stara się być jak najbardziej angażująca, aby z czasem stać się ważnym elementem życia adresata. Same media społecznościowe są narzędziami, najczęściej niepłatnymi, pozwalającymi w prowadzeniu nieustannego dialogu z obecnymi fanami marki i potencjalnymi przyszłymi - gdyż pozwala to również nawiązywać bliskie relacje z ludźmi.

Budowanie tej szczególnej więzi jest możliwe dzięki ciągłemu kontaktowi z odbiorcą opartemu na dialogu. Doskonale w takiej sytuacji sprawdzają się social media. Dzięki działaniom w social mediach marka staje się widoczna dla ludzi. Oprócz tego pozwalają one na tworzenie własnej zawartości. Takimi narzędziami są blogi - czyli dzienniki internetowe, serwisy wideo i foto, portale społecznościowe, fora, a nawet podcasty i radia internetowe.

Jednym z najchętniej uczęszczanych portali społecznościowych jest Facebook. To właśnie on dzięki oferowanej feerii możliwości działań, jakie można w jego ramach wykorzystać, stał się mocno preferowanym narzędziem do kreowania marek osobistych poprzez budowanie więzi i relacji z klientem. Sukcesy generowane przez marki osobiste wykorzystujące Facebook do działań relacyjnych nie są już tylko incydentalne, ale przy odpowiednim zaangażowaniu samej marki stają się niemal normą. Jest to doskonałe źródło motywacji, ale również pomysł na innowacyjne działanie biznesowe, które właśnie dzięki silnemu spersonalizowaniu takich działań może pozwalać na wygenerowanie zupełnie nowej jakości na rynku.

\section{Bibliografia}

Bogan Ch.E., English M.J., Benchmarking jako klucz do najlepszych praktyk, Helion, Gliwice 2006.

Brzozowska-Woś M., Social media and brand image, Uniwersytet Ekonomiczny w Krakowie, Kraków 2013.

Bucki P., Personal Branding, „Nowe Kompetencje”, 1.04.2014, http://blog.nowekompetencje.pl/ artykuly/personal-branding [dostęp: 3.01.2015].

Budek K., Marka osobista - klucz do kariery, http://manager.nf.pl/marka-osobista-klucz-do-kariery,,47819,24 [dostęp: 3.01.2015]. 
Evans L. „Li”, Social Media Marketing. Odkryj potencjał Facebooka, Twittera i innych portali społecznościowych, Helion, Gliwice 2011.

Facebook notuje rekordowe wyniki, „Forbes”, 30.07.2015, http://www.forbes.pl/facebook-notuje-rekordowe-wyniki,artykuly,197681,1,1.html\# [dostęp: 30.07.2015].

Fanpage Trends 06.2015, „Sotrender”, http://www.sotrender.pl/trends/facebook/reports/201506/ ludzie\#trends [dostęp: 30.07.2015].

Halligan B., Shah D., Inbound marketing, Helion, Gliwice 2010.

Ile czasu w sieci spędza statystyczny Polak?, WP finanse, 6.11.2015, http://finanse.wp.pl/ kat,1033701,title,Ile-czasu-w-sieci-spedza-statystyczny-Polak,wid,17956845, wiadomosc. html?ticaid=1184f0 [dostęp: 1.11.2015].

Jaskowska B., Raport: zaczynamy akceptować marki w serwisach społecznościowych, „InternetStandard”, 24.03.2010, http://www.internetstandard.pl/news/357280/Raport.zaczynamy. akceptowac.marki.w.serwisach.spolecznosciowych.html [dostęp: 11.03.2014].

Leśniewska A., Reklama internetowa, Helion, Gliwice 2006.

Marchwicki M., Facebook rządzi i dzieli, „SocialPress”, 27.04.2015, http://socialpress.pl/2015/04/ facebook-rzadzi-i-dzieli/\# [dostęp: 10.06.2015].

Mazurek G., Promocja w Internecie. Narzędzia, zarządzanie, praktyka, Ośrodek Doradztwa i Doskonalenia Kadr, Gdańsk 2008.

Prejs A., Facebook w Polsce - podsumowanie 2014 r. - infografika, „Sotrender”, 2.02.2015, http:// blog.sotrender.com/pl/2015/02/facebook-polska-2014/ [dostęp: 3.06.2015].

Rogoziński K., Nowy marketing ustug, Wydawnictwo Akademii Ekonomicznej w Poznaniu, Poznań 1998.

Statystyczny Polak spędza w sieci ponad 70 godzin miesięcznie. Nie każdy potrafi w pełni wykorzystać cyfrowe możliwości, Biznes NewSeria, 5.11.2015, http://www.biznes.newseria.pl/ news/statystyczny_polak_spedza,p1201126379 [dostęp: 1.12.2016].

Szubert A., Każdy z nas ma markę osobistą. Jak uczynić ją silną?, „naTemat”, 5.09.2014, http:// annaszubert.natemat.pl/115899,kazdy-z-nas-ma-marke-osobista-jak-uczynic-ja-silna [dostęp: 3.01.2015].

W Newsweeku: Ewa Chodakowska - trenerka - killerka - milionerka?, „Newsweek”, 10.11.2013, http://biznes.newsweek.pl/trenerka-killerka-milionerka-ile-zarabia-ewa-chodakowska-,artykuly,274327,1.html [dostęp: 21.05.2015].

Walker Rettberg J., Blogging: Digital Media and Society Series, Polity Press, Cambridge 2014.

Wheeler A., Kreowanie marki, Wydawnictwo Naukowe PWN, Warszawa 2010.

Wojciechowski M., Psychologia sprzedaży. Permission marketing, http://clienting.blox.pl/2008/05/ Permission-marketing.html [dostęp: 1.10.2015].

Wołyński J., Marka osobista, 2011, http://jakubwolynski.pl/marka-osobista/ [dostęp: 21.05.2015]. 